\title{
The Responsibilities of the Church in Education of Politics in Indonesia
}

\author{
Putri Hergianasari* \\ Universitas Kristen Satya Wacana
}

*Corresponding Author: Putri Hergianasari, Universitas Kristen Satya Wacana

\begin{abstract}
Many ways of understanding fundamentalism radicalism are spread, especially in this technological era, namely through the internet and social media. Negative impact has arisen from the spread of radicalism. This impact is very dangerous for the nation and also the church maintains stability, security, and peace. The research model used in this study is qualitative. Participatory research, personal intensive interviews, observation processes and focus group discussions (FGD) in order to understand the experiences of key informants, and we can find firm attitudes from these informants. The data collection method used is descriptive qualitative. The results of this study found that radicalism and religious fundamentalism are religious movements that seek to completely overhaul a social atmosphere or political order that exists by using violence. The factors that influence the emergence of this understanding, are nationalism, religion, globalization, thought, economy, (poverty and inequality), powerful political and weak state, lack of awareness of life according to Pancasila, social, ideological, psychological and educational. The responsibility of the church in deradicalizing radicalism is to educate people to carry out God's commands in the law of love, namely goodness, justice, and peace. The church is obliged to carry out a program with the government, namely deradicalization. The result of this paper is the role of the church in deradicalization, among others, Support government policies and programs in preventing terrorism and radicalism, build networks, dialogue and cooperation with the government, churches, mass organizations, and other moderate religious groups, Become "eyes and ears" against threats and potential threats of radicalism, Actively involved in social activities with the community around the church, Establish dialogue with the surrounding community.
\end{abstract}

Key words: Church, Politics, Dedadicalization, Indonesia

\section{INTRODUCTION}

Based on the results of research from the Populi Center it can be informed that there was a very significant change where in January and February 2017 the majority of the people did not agree to have leaders who were not of their religion, which had a value of 48.7 percent and who agreed by 28 percent.(1) Interesting findings obtained by the community to elect leaders who were not of the same religion as the majority of the people where the elections were held decreased very significantly, although it still ranked first. In the study, it was also stated that the higher the level of leadership of the regional head and the wider the authority, the stronger the problems of religious sentiment and identity that plagued. The Annies-Sandy team's win has a positive-linear relationship with the declining level of community satisfaction on the incumbent Governor's leadership performance. Meanwhile, in relation to the behavior of political campaigns, as recorded in the BBC Indonesia news portal, they use places of worship to explain the types of work programs when elected as Governor. As reported by the news portal, the candidate pair made a strategy to attract Muslim voters through symbols and terms that are associative with religious identity.(2)

Based on research conducted by Populi, there has been a tendency for politics in Indonesia recently to use the horizontal issue as a tool to attract the sympathy of the masses. This is demonstrated by the efforts to thicken identity politics in various regions of the local elections by various candidates. Where exhaled identity politics always refer to exhaled horizontal issues ranging from religious, ethnic, indigenous and non-indigenous issues that make people divided. In front of us, the political agenda will come almost at the same time. After the Jakarta elections which has succeeded in dividing 
the community with colored of religion and identity issues, in 2018 there will be simultaneous local elections in Indonesia, followed by 171 regions. Will be followed by legislative elections and elections in 2019 which are held simultaneously.(3)

Political propaganda, political promises in the re-campaign will be busy coloring various political contestations. Persuasion is a common thing to do to attract public sympathy and support. However, the thing that must and must be remembered and done is that the propaganda, campaigns and political publicity that will be carried out by anyone who participates in political contestation, must pay attention to their political responsibilities. Do not let issue of religion and identity issues be deliberately used as a means of dividing the Indonesian nation which is a pluralist nation caused by power ambitions.(4)

\section{THEORITICAL BACKGROUND}

Based on the views of Michael Pfau and Roxanne Parrot, in the book Persuasive Communication Campaign(5), argues that the campaign is a consciously designed, gradual and ongoing process that is carried out at a certain time frame with the aim of influencing the target audience or masses. Construction of the meaning of the campaign, it is clear that each campaign action is communication that has a specific purpose, consciously, and with a design that has been considered. In political marketing, branding, positioning and segmenting, often moves are not in accordance with social and political ethics. It often moves towards extremism that plays and endangers the unity of the nationstate, aiming to obtain a "seat" by exploiting and reviving primordial social networks. With the support of a political consultant who directs primordial issues that can mobilize the masses to win votes.(6)

In the approach of Social Judgment Theory, Muzafer Sherif and Carolyn Sherif who were followed in Richard M Perl off in his book, The Dynamic of Persuasion.(7)The persecuted audience is divided into three zones. First, the latitude of acceptance or acceptance zone, candidates as persuaders can be accepted and tolerated. Second, the latitude of rejection or rejection zone, this condition is seen from the emergence of resistance or the position opposite the candidate. Third, the latitude of commitment, when the candidate is not accepted, but not rejected. In order to get a place for the acceptance of the audience earlier, many candidates were finally trapped in a political strategy of deliberately dividing society. Did not rule out the possibility that the candidate also performed theatrical as if pro to diversity. And if the mass media preach and duplicate coverage related to the religion and identity issue on an ongoing basis. Did not rule out the same thing will be used as a campaign strategy for candidates in the 2018 elections and 2019 elections to come.(8)

Every candidate who wins political contestation must face the same reality, which is fulfilling the campaign promise. The community will control and collect promises on the campaign narrative that has been carried out by the candidate. Walter Fisher in his book Human Communication as Narration: Toward a Philosophy of Reason, Value, and Action (1987), explains the importance of building narrative rationality.(9)Not all narratives have the same power to gain trust. Two rational principles of the narrative are coherence and truth. Narratives in the campaign can be interpreted as symbolic actions of words or actions that have different meanings in interpreting. This is the political responsibility of the winners of the contest by realizing campaign promises, not merely as jargon and tools that are solely used to gain power but to divide the community. It becomes acomplicatedpublic relation if the divisive narrative finally gets the support of the masses because to be the leader of the product will be difficult to unite the community.

Coherence will emerge if the winner as a communicator builds and develops a narrative that can be presented coherently and consistently. For example, during the Anies-Sandi campaign which clearly stated rejecting reclamation. Is this than a real commitment to the implementation process? Structural coherence will arise if the elements of a narrative can coherently flow. One may imitate himself in such a way that the construction of people's thoughts on him is well-formed. However, when carrying out the leadership function, his character in leading will shape his political reputation.(10)

The truth factor is the reliability of a narrative, which means that the statements are relevant to the existing social reality. If the campaign promises are only a tool and are not realized, it will cause the weakening of public trust. Campaign promises often lose their rationality, so it is not easy to realize 
these promises and it is not easy, if political promises are built that make people divided, it is not easy to reunite.
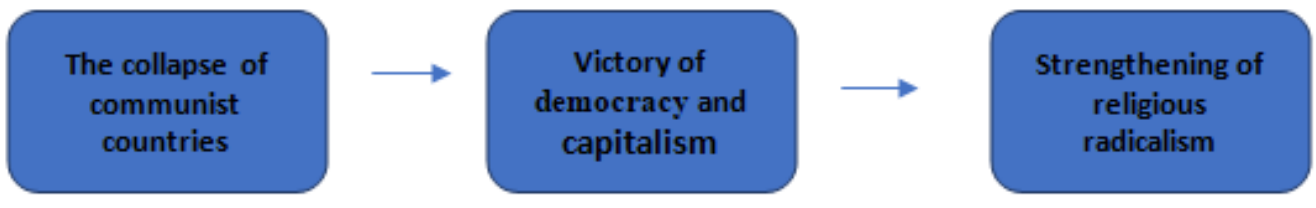

Figure1. Post-Cold War Political Shift

From this figure, explains that the international situation is dynamic. Issues that develop in the international world also impact on the regional and even domestic levels. The threat of terrorism and radicalism is a threat that is cross-country and has networks and activities that are scattered and closed. So, in handling it really requires collective handling and joint action through capability collaboration and interaction between countries that are intensive, constructive and concrete. Radicalism which leads to terrorism becomes an important issue for Indonesian Muslims today. These two issues have caused Islam.

Labeled as a religion of terror and Muslims considered to be fond of violence holy to spread his religion. Even though the assumption is easy countered, but the fact that the terrorist in Indonesia is a personHardline Muslims weigh heavily on the psychology of Muslims as a whole. In the context of Indonesia, acts of terrorism that occurred in Indonesia have ideological, historical and political links and are part of the influence of the strategic environment on the global level as well regionally. Despite the acts of terrorism that occurred in Indonesia the last few years have mostly been carried out by Indonesians and only a few people as intellectual actors from abroad, but it cannot be denied that the act of terrorism at present is a combination of domestic actors and those who have transnational networks.

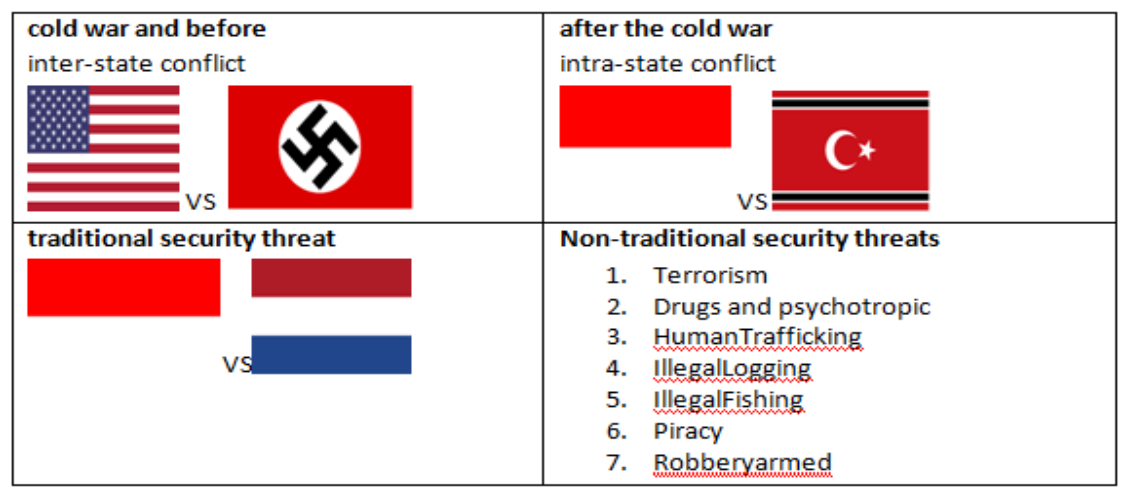

Figure2. Shifting Security Threats

The figure 2 above is evidence that in the era of cold war conflict occurred between superpowers, namely the United States and the Soviet Union, after the post-cold war there was conflict within the state. Then a security problem of a country is divided into two, namely the traditional problem in which Indonesia was colonized by the Dutch for 350 years. And the second is non-traditional security threats, where terrorism is one of the crucial problems. 


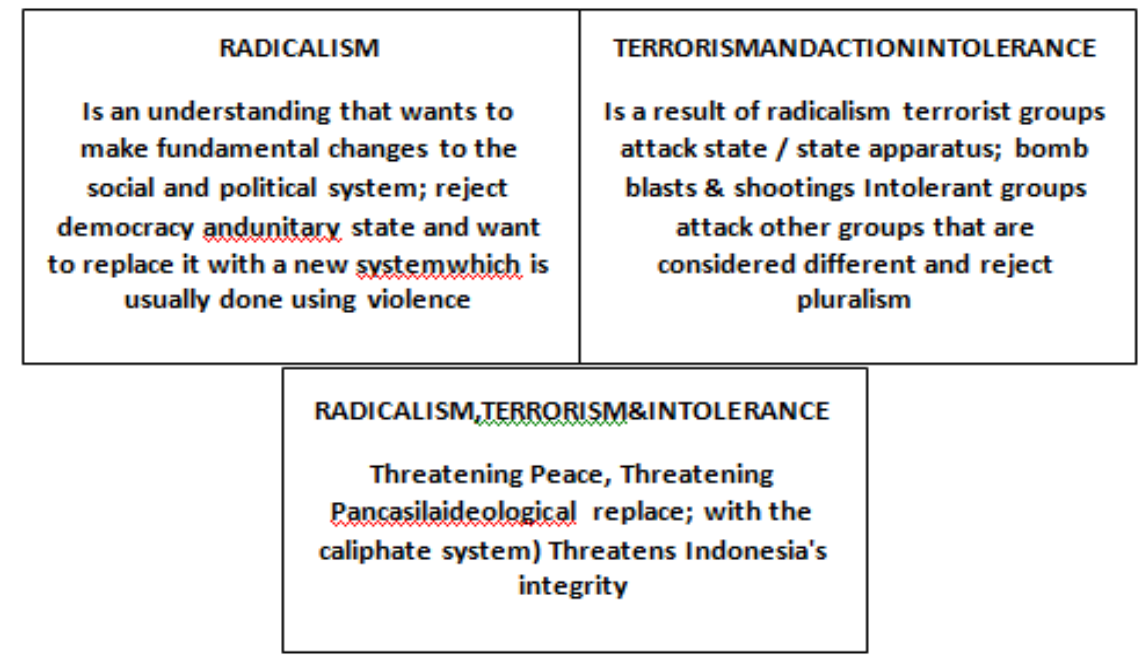

Figure3. Radicalism, Terrorism and Intolerance

From the figure above, it can be seen that there is a mutual relationship between radicalism, terrorism and intolerance. Indonesia as one of the countries inhabited by populations with a majority of Muslims, is a perfect target in the discourse of this act of terrorism. Discourse about the number of networks and fundamental Islamic movements that grow and develop in Indonesia is one of the separate indicators of these accusations. Attitudes and accusations directed at adherents of Islam itself are not without precedent.

They might not dare to openly oppose Pancasila. However, most of them regard Pancasila as equal and equal to human rights and democracy, ideologies of human creation that are not worthy of deification. They consider the three as toghut, the result of human mind processing that becomes worshiped. Sooner / later they intend to overthrow and replace it with God's law. From here comes the thesis of the "democratic trap" among social scientists: radical groups use democracy and human rights to kill both. In this country a number of NGO's use human rights and democratic arguments to justify their religious ideology and understanding, even though they are very loud and explicitly against both.

\begin{tabular}{|l|}
\hline Economy: unemployment and poverty \\
\hline Politics: Perception is treated unfairly by global politics, and politics national \\
\hline Psychology: anger, revenge, disappointment \\
\hline Ideology: narrowing or misinterpretation of religious teachings \\
\hline $\begin{array}{l}\text { Media: Spread of Provocation, Agitation and Propaganda, ideas, radicals, recruitment of } \\
\text { terrorism, hate speech }\end{array}$ \\
\hline
\end{tabular}

Figure3. Problems of Radicalism

In the picture above states that the factors causing terrorism are economy, unemployment and poverty politics, perception is treated unfairly by global politics, and national politics. Psychology, anger, revenge, disappointment. Ideology, narrowing or misinterpretation of religious teachings. Media, spread of provocation, agitation and propaganda, ideas, radicals, recruitment of terrorism, hate speech. The radical group (terrorism and intolerance) in Indonesia became increasingly prevalent in the action in the late 1990s, together with the change in the Indonesian government which was more democratic.

\section{RESEARCH METHODS}

This study uses a qualitative approach (qualitative methods) that refers to various techniques in research; participatory research, personal intensive interviews, observation processes and focus group discussions (FGD) in order to understand the experiences of key informants, and we can find firm attitudes from these informants. This research uses grounded theory as a research design, for several reasons: First, research on intolerance, radicalism and terrorism is related, with social processes or social action, with an emphasis on the question: how is the role of the church in helping community de-radicalization.

Second, this research is intended to find and develop a theory, which explains the role and responsibilities of the church in the de-radicalization which is a concern and concern. Third, as a 
method that emphasizes the discovery and development of theories from empirical data in the field, grounded theory or grounded research is considered sufficient, to be used as a tool in explaining the responsibilities of the church in deradicalization. This research is a qualitative research, which examines the phenomenon of intolerance, radicalism and terrorism in people's lives, therefore to obtain field data, researchers conduct research on the unity of the church in Indonesia. Qualitative data collection methods, which are complemented by literature studies and field situation observations. Considering the purpose of exploring real experiences and capturing meaning, which is actually created in the field of research through direct interaction between the researcher and the investigator, it is necessary to ensure that the findings in this study truly reflect the situation of the research object (valid) and tend to have consistency. by using triangulation to confirm field data, observations and relevant literature.

\section{Politics BaSed ON THE Bible}

According to the Bible, politics is a conscious effort and process to understand and interpret political reality from the perspective and mindset of the Bible. The question what does the Bible say about politics? What is the actual conception and political system contained in the Bible? How do you correctly translate it into reality? Or more precisely, how do political concepts or doctrines experience humanization and worldliness? Departing from this question, exploration of the political conception of the Bible is carried out.

Political words (city) appear firmly in Jeremiah (29: 7): And seek the peace of the city and pray to the Lord for it, for in its peace you will have peace. Looking for or striving for the welfare of the city (politics), is clearly the mandate of the Bible in God's people. Thus, political arrangement cannot be separated from God's affairs in all places, space and time. The mandate or command of the Bible to be politicized for the people in the book of Jeremiah, is not necessarily followed by a form or system, especially when it comes to detailed political procedures and mechanisms. An important question arises: Does the Bible give empty concepts or give freedom to the people, especially the leaders? It seems that the religious answer is freedom. The Bible does not provide a dead nail, the standard and overall concept regarding the realization of that political effort. The political formula is not a matter for the Bible, but rather a necessity formulated by God's people. The Bible only provides a very fundamental concept, to seek peace (seeking political prosperity). To the people of God, the Bible provides the broadest opportunity to formulate political formulas, both concerning the basis and political system, forms, procedures and mechanisms of government. The Bible only gives one stress and a certainty of well-being.

\section{What IS THE ChURCh'S RESPONSIBILITY IN POLITICS?}

\section{Christ's power is manifest in politics}

This means that also in the political sphere there can be no God but Allah. Because the biggest danger in politics is idol worship, defending something that is not God. Ideology can be God. We must dare to refuse and take responsibility so that this does not happen. All and anything including ideology, figures, leaders and nation is not God. They must submit and submit to the one God.

\section{Christ's peace is manifested in political life}

This means that the spirit of the love and forgiveness of Christ comes true. The practice of political life very often becomes very cruel and violent. Different opinions and interests are enemies and must be crushed. There are no eternal friends and enemies, only eternal interests. This is a big mistake in politics. The responsibility of the Church is the responsibility of peace. The political mission of the Church is the mission of reconciliation. Promotes harmony and social solidarity without regard to differences in class, ethnicity, sects and descent.

\section{Christ's renewal program must underlie political programs}

This means that every process, product or political policy is based on the teachings of Christ. Courage to learn from past mistakes and sincerity to change yourself because in life there is usually a desire to change but are reluctant to change. The world will change if each is able to change themselves

\subsection{What is the Church's Responsibility in Politics?}


The church must be responsive to the issues, problems, developments and upheavals facing its congregation and this nation. The church must be able to cry out its prophetic voice and contribute and solutions to the problems facing humanity. The church must play a role in addressing the Two Ministerial Decree on licensing the establishment of houses of worship. This is marked by the prohibition of worship by some groups. As a result, freedom of worship is disrupted. In addition, the Church must also be sensitive to regional autonomy. Many local regulations or policies of regional authorities are discriminatory. Another problem is the increase in fuel that is not in favor of the people, the economy has not improved, the welfare and prosperity of the people is still low and uneven, the disintegration of the nation, corruption, the rule of law, the quality of education is still low and so on. In the 1983 World Council of Churches (DGD) session in Vancouver Canada, initiated by the Churches of third world countries, a kind of political theology emerged, that "the Church must side and defend the poor, the oppressed and the marginalized. Because Jesus has proven this (Matthew, Mark, Luke, John). Likewise in the time of the prophets (Isaiah, Amos, Jeremiah).

To carry out and realize the Church's view of the government is carried out according to the Gospel of Romans 13, Matthew 22: 15-22. The implementation is filled with positive, constructive, and realistic criticism. Church members, church leaders are expected to be more involved and involved in political institutions, be they the executive, legislative and judiciary, public institutions and study groups. After that is realized, the church must be able to utilize these members, by being able to consult and work together to discuss real political life and in accordance with God's plans and will. And as an institution or organization the church must be able to make itself as an authoritative institution so that the church can be used as the last bastion for the congregation in seeking truth and justice in the midst of this world.

\section{CONCLUSION}

Full responsibility in politics does not mean we have to become political institutions, or churches that are politicized for certain interests. A politician's orientation or ultimate goal is power. For the church what matters is not who holds power, but how the person exercises power. Anyone if exercising power properly must be supported. When it's bad you have to be reminded and even opposed.

The role of the church in deradicalization, among others, Support government policies and programs in preventing terrorism and radicalism, build networks, dialogue and cooperation with government, churches, mass organizations and other moderate religious groups, become "eyes and ears" against threats and potential threats of radicalism, actively involved in social activities with the community around the church, Establish dialogue with the surrounding community

We can only take full responsibility in politics if we feel ourselves as a full part of society, nation and state. There is no aspect or anything that is independent of politics. Because religion and politics are like two inseparable things. We are citizens of the Kingdom of Heaven, but we can be good citizens of the Kingdom of Heaven if we first become responsible citizens where we live.

\section{REFERENCES}

[1] Populi Center | WAJAH BARU IDAMAN WARGA JAKARTA DI PILGUB DKI 2017 [Internet]. [cited 2020 May 20]. Available from: http://populicenter.org/wajah-baru-idaman-warga-jakarta-di-pilgub-dki2017-22-februari-2016/

[2] Religion, power and politics in Indonesia - BBC News [Internet]. [cited 2020 May 20]. Available from: https://www.bbc.com/news/world-asia-39650150

[3] Purbolaksono A, Setyaningsih E, Basrianto F, Wicaksono R, Lutfiah U, Nainggolan Y. Adinda Tenriangke Muchtar. :92.

[4] Welch D. The Third Reich: politics and propaganda [Internet]. London; New York: Taylor \& Francis eLibrary; 2007 [cited 2019 Sep 29]. Available from: http://public.eblib.com/choice/publicfullrecord.aspx $? \mathrm{p}=331034$

[5] Pfau M, Parrot R. Persuasive communication campaigns. Boston: Allyn and Bacon; 1993.

[6] Hergianasari P. BRIEF STUDY OF ANALYZING IDEOLOGICAL DIMENSION OF ISLAM RADICAL IN INDONESIA. PEOPLE: International Journal of Social Sciences [Internet]. 2019 Sep 28 [cited 2020 May 20];5(2). Available from: https://grdspublishing.org/index.php/people/article/view/2116

[7] Perloff RM. The dynamics of persuasion: communication and attitudes in the 21 st century. 2 nd ed. Mahwah, N.J: Lawrence Erlbaum Associates; 2003. 392 p. 
[8] Strömbäck J, Grandien C, Falasca K. Do campaign strategies and tactics matter? Exploring party elite perceptions of what matters when explaining election outcomes. Journal of Public Affairs. 2013 Feb 1; $13: 41-52$.

[9] Fisher WR. Human communication as narration: toward a philosophy of reason, value, and action. University of South Carolina Press; 1987. 224 p.

[10] (PDF) RE-BRANDING PERSONAL ANIES BASWEDAN DI KALANGAN PEMILIH PEMULA: ANALISIS ISI KAMPANYE "tweet jahat" PASLON ANIES - SANDI PADA PILKADA DKI 2017 [Internet]. ResearchGate. [Cited 2020 May 20]. Available from: https://www.researchgate.net/publication/ 327226645_RE_BRANDING_PERSONAL_ANIES_BASWEDAN_DI_KALANGAN_PEMILIH_PEMU LA_ANALISIS_ISI_KAMPANYE_tweet_jahat_PASLON_ANIES_SANDI_PADA_PILKADA_DKI_2 017

\section{AUTHORS' BIOGRAPHY}

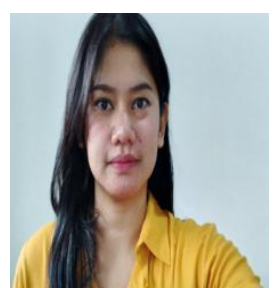

Hergianasari is a lecturer at a private university in Indonesia, Satya Wacana Christian University. graduated bachelor in political science study program in 2010 and graduated master in political analysis program in 2013 at Airlangga University. Became a lecturer in 2016 on International Relations study program. research focus on domestic and foreign political issues, and focus on radical movements in a political perspective.

Citation: Putri Hergianasari. "The Responsibilities of the Church in Education of Politics in Indonesia" International Journal of Humanities Social Sciences and Education (IJHSSE), vol 7, no. 8, 2020, pp. 01-07. doi: https://doi.org/10.20431/2349-0381.0708001.

Copyright: (C) 2020 Authors. This is an open-access article distributed under the terms of the Creative Commons Attribution License, which permits unrestricted use, distribution, and reproduction in any medium, provided the original author and source are credited. 